Beche Bt Mamma | Decentralization in Indonesia:

an Evaluation of the Implementation of Laws 22 and 25 of 1999

\title{
Decentralization in Indonesia: An Evaluation of the Implementation of Laws 22 and 25 of 1999
}

Beche Bt Mamma*

bechemamma@yahoo.com

\begin{abstract}
Indonesia has been undergoing a reform process. It started with the process of rapid decentralization government began in 1999 from a strong centralized system. One of its process is the introduction of decentralization, a process of transfer power from the central government to provinces to subprovinces. Decentralization became a worldwide phenomenon since over three decade. Countries around the world use decentralization principles with varying degree, mostly by transferring responsibilities of public service delivery to lower levels of government. The decentralization literature promotes the good governance aspects associated with decentralization including local citizen participation, democratic elections and financial and political equity. Decentralization in Indonesia is much more of an administrative decentralization rather than a fiscal decentralization. The central government continues to control a vast share of the revenues required for local governance under true decentralization.
\end{abstract}

Key words: Decentralization, Reform Process, Centralized System, Governance

*International Relation's Lecture at Bosowa University 
Beche Bt Mamma | Decentralization in Indonesia:

an Evaluation of the Implementation of Laws 22 and 25 of 1999

Indonesia has been undergoing a reform process. It started with the process of rapid decentralization government began in 1999 from a strong centralized system. One of its process is the introduction of decentralization, a process of transfer power from the central government to provinces to subprovinces. ${ }^{1}$ This paper will assess the implementation of decentralization in Indonesia under new decentralization guidance in 2001 under law 22/1999 on regional government and law 25/1999 on fiscal balance between the central and regional government in $2004 .^{2}$ Therefore, the first part of this essay will explain the background of decentralization process in Indonesia which caused the two laws that mentioned above to be enacted. Then it willassess strengths and weaknesses of decentralization in Indonesia since the decentralization was introduced in 1999.

\section{Decentralization in Indonesia}

Decentralization became a worldwide phenomenon since over three decade. Countries around the world use

${ }^{1} \mathrm{~K}$. Green, Decentralization and Good Governance: the case of Indonesia, Munich Personal rePEcArchieve, MPRA Paper no. 18097, 26 October 2009, p. 1.

${ }^{2}$ See R. E. D. Darmawan, The Practices of Decentralization in Indonesia and Its Implication on Local Competitiveness, Public Administration-Public Governance Study, School of Management and Government, University of Twente, Enschede, The Netherlands, 2008, p. ii. decentralization principles with varying degree, mostly by transferring responsibilities of public service delivery to lower levels of government. ${ }^{3}$ Many countries around the world have embraced decentralization over the past ten years in regions as diverse as the newly independent states of Eastern Europe, Mozambique, Brazil, India, and Indonesia. The decentralization literature promotes the good governance aspects associated with decentralization including local citizen participation, democratic elections, and financial and political equity. ${ }^{4}$ Decentralization in Indonesia is much more of an administrative decentralization rather than a fiscal decentralization. The central government continues to control a vast share of the revenues required for local governance under true decentralization. Local governments on average receive more than 80 percent of their revenues from the central government. This creates a disconnectingbetween revenues received at the local level and expenditure decisions

${ }^{3}$ R. R. Simatupang, Evaluation of Decentralization Outcomes in Indonesia: Analysis of Health and Education Sectors, A Dissertation Submitted in Partial Fulfillment of the Requirements for the Degree of Doctor of Philosophy in the Andrew Young School of Policy Studies of Georgia State University, 2009, p. 1.

${ }^{4}$ K. Green, Decentralization and Good Governance: the case of Indonesia, Munich Personal rePEcArchieve, MPRA Paper no. 18097, 26 October 2009, p. 1. 
Beche Bt Mamma | Decentralization in Indonesia:

an Evaluation of the Implementation of Laws 22 and 25 of 1999

that are made locally. Local governments are responsible for paying salaries that were previously paid for by the central government and paying for basic required services such as health and education. Consequently, local governments have increased spending responsibility without the additional locally controlled revenue base necessary to support extra spending. Decentralization is a national development policy that can yield national development outcomes. ${ }^{5}$ As Simandjuntak suggests 'through decentralization various national problems will be solved at the regional level by using local means to cope with local challenges'. ${ }^{6}$ It is important to know that the decentralization process in Indonesia according to the World Bank has started off much better than expected. As a result, Indonesia becomes center of attention from international scholars as they often mentioned about Indonesia's decentralization as an example in their works. $^{7}$

\footnotetext{
${ }^{5}$ K. Green, p. 4.

${ }^{6}$ T. B. Pepinsky and M.M. Wihardja, Decentralization and Economic Performance in Indonesia, 10 December 2010 , ,http://www.researchgate.net/publication/22 8427343_Decentralization_and_economic performance_in_Indonesia/links/004635242 ae 33 e 3 ca4000000, consulted on 12 November 2014.

${ }^{7}$ R. R. Simatupang, Evaluation of Decentralization Outcomes in Indonesia: Analysis of Health and Education Sectors, A Dissertation Submitted in Partial Fulfillment of the Requirements for the Degree of Doctor of
}

Indonesia is a unitary state. So that provincial and local governments are the creation of the central government. In the colonial period, government administrative was highly centralized, although municipalities were more autonomous than at present. ${ }^{8}$ In addition, local infrastructure services in Indonesia are developed and operated in a multitier and complex system of regional administration. So that, central government ministries and their regional offices are expected to work cooperatively with agencies of provincial and local governments in planning and implementing development projects and providing services. ${ }^{9}$ Indonesia today is comprised of 30 autonomous provinces that contain districts and municipalities. Districts, located in rural areas, and municipalities, outside of rural areas, are the same level of government. The provinces have a governor who serves as the central government's representative and a representative parliament. The provinces and local governments are subnational governments. ${ }^{10}$ According to Green, regional autonomy legislation was drafted in 1999 (Law 22 and Law 25) and

Philosophy in the Andrew Young School of Policy Studies of Georgia State University, 2009, p. 1.

${ }^{8}$ P. Smoke and B. D. Lewis, Fiscal Decentralization in Indonesia: A New Approach to an Old Idea, World Development, vol. 24, no. 8, p. 1282.

${ }^{9}$ P. Smoke and B. D. Lewis, p. 1282.

${ }^{10}$ K. Green, p. 3. 
Beche Bt Mamma | Decentralization in Indonesia:

an Evaluation of the Implementation of Laws 22 and 25 of 1999

implemented in 2001, the decentralization

law focused on empowering subprovincial governments and were crafted without a well-developed transition or implementation plan. ${ }^{11}$

\section{Decentralization practice in Indonesia based on Law 22 and Law 25}

Similarly, according to Darmawan, along with the reform that took place in 1998, the new decentralization were prepared under the escalating pressures of the disintegration and demands for more democratic government from the civil societies and international donors at that time. Thus, law no. 22/1999 on regional government and law no. 25 on fiscal balance between central and regional government were enacted on May 1999 and it was effective in January $2001 .{ }^{12}$ To complete the process of preparation period, it took two years for all levels of governments to fully implement the laws. ${ }^{13}$ This laws emphasize on how decentralization should be carried out. These laws are designed to involve more powers to the district governments. In addition, as an emerging democracy country, this change is also accentuated by the Western international donor that tends to promote decentralization as a means of

${ }^{11}$ K. Green, p. 3.

12 R. E. D. Darmawan, p. 23.

${ }^{13}$ R. E. D. Darmawan, p. 24. devolution of powers to improve democratization in Indonesia. ${ }^{14}$ Further, Darmawan argues that 'the newest decentralization laws have different emphasize on how decentralization should be carried out. These laws are designed to devolve more powers to the district governments. Besides, as an emerging democracy country which has been engaging in a reform, this change is also accentuated by the western international donors' involvement that tends to promote decentralization as a means of devolution of powers to improve democratization'.

According to Akhmad Bayhaqi the Law No 22/1999 and 25/1999 in Indonesia, divide decentralization into two categories, Law 22 concerns administrative decentralization, while Law 25 concerns financial administration. ${ }^{15} \mathrm{As}$ of January 2001, based on Law No 22/1999 and Law No 25/1999, the Indonesia's government must have already implemented the new policy of regional

\footnotetext{
${ }^{14}$ R. E. D. Darmawan, p. 24.

${ }^{15} \mathrm{~A}$. Bayhaqi, Decentralization in Indonesia: the Possible Impact on Education (Schooling) and Human Resource Development for Local Regions, Southeast Asian Studies Programme National University of Singapore, 2004, p. 3. Paper presented at The 2nd International Conference on Indonesia: Decentralization and Structural Reformation, Faculty of Social and Political Sciences, Diponegoro University, Semarang, July 78th,2004.http://www.rand.org/content/dam/r and/www/external/labor/FLS/IFLS/papers/2 004_bayhaqi.pdf, consulted on 12 November 2014.
} 
Beche Bt Mamma | Decentralization in Indonesia:

an Evaluation of the Implementation of Laws 22 and 25 of 1999

autonomy, the Laws provided the framework for decentralizing authorities once held by central government and gave local government's new responsibilities to manage their own regions. ${ }^{16}$ This decentralization and special autonomy laws derives from Central government to the local governments in term of the authority and corresponding responsibility for the delivery of most basic services. ${ }^{17}$ However, as Bert Hofman and Kai Kaiser argue Law 22 of 1999 gives broad autonomy to the regions in all but a few tasks that are explicitly assigned to the center, including defense, justice, and police and planning. With the authority come the resources. In the first year, the regional share in government spending jumped from 17 percent to 30 percent. Over time, with the current assignments of functions, this share is likely to rise to over 40 percent, a sharp contrast with the average 15 percent of spending in the 1990s. This share is also much larger than can be expected on the basis of Indonesia's size - whether measures in population or geographical size. In addition to spending, much of the apparatus of government was put under the control of the regions. Over 2 million civil servants, or almost $2 / 3$ of the central government workforce, was transferred to the regions. Now, out of a

${ }^{16}$ A. Bayhaqi, p. 11.

${ }^{17}$ A. Bayhaqi, p. 11. civil service of 3.9 million, some 2.8 million are classified as regional. And 239 provincial-level offices of the central government, 3933 local-level offices, more than 16,0000 service facilities-schools, hospitals, health centers-- were transferred rock stock and barrel to the regional governments throughout Indonesia. ${ }^{18}$

\section{Flaws in Implementation}

In line with Hotman and Kaiser's argument in regards with the task divisions, Darmawan argues that due to the too short and hurried preparation, the implementation of this laws caused potential flaws and have inevitably started to produce adverse effects. ${ }^{19}$ For example, during their short implementation period, several problems are identified, such as unclear division of authorities among the tiers of government causing a struggle for authorities among them, inefficient resource allocation caused by the low capacity and demoralization of civil servants within the regional governments, widening disparity among regions, and

\footnotetext{
${ }^{18}$ B. Hofman and K. Kaiser, The Making of the Big Bang and Its Aftermath: A Political Economy Perspective, Paper presented in the Conference : Can Decentralization Help Rebuild Indonesia?, A Conference Sponsored by the International Study Program, Andrew Young School of Policy Studies, Georgia State University, May 1-3, 2002, p. 2,

http://www1.worldbank.org/publicsector/Learning Program/Decentralization/Hofman2.pdf, consulted on 13 November 2014.

${ }^{19}$ R. E. D. Darmawan, p. 24.
} 
Beche Bt Mamma | Decentralization in Indonesia:

an Evaluation of the Implementation of Laws 22 and 25 of 1999

stronger primordial ties based on ethnic and religion. ${ }^{20}$ Moreover, the confusion started when the provinces are also mentioned as one of autonomous regions, while at the same time they retain into hierarchical relationship with the central government. Consequently, it leads to a de facto deconcentration practice. It would be clearer if it is stated that the provincial regions are excluded from being called as autonomous regions, since the true devolution only occurs at the regency and municipality level as they are detached from the higher level of government. ${ }^{21}$ In addition to that, the laws also declare that for the reason of economic and governance efficiency, one or more regions can be merged if they cannot perform the regional autonomy appropriately, or conversely, a new region can emerge once it has complied with the requirements. However, an amalgamation of some regions into one region or a split into new regions, could be not right in the political sense, because it can raise potential threats of conflict of interest among the communities to get the power over the new formed regions. ${ }^{22}$ Under the previous law, this

${ }^{20}$ R. E. D. Darmawan, p. 24.

${ }^{21}$ R. E. D. Darmawan, p. 25.

${ }^{22}$ See Amri, PuspaDelima. (2000).

Dampakekonomidanpolitik UU No. 22 dan 25 tahun 1999 tentangotonomidaerah. (The political and economy impacts of Law No. 22 and $25 / 1999$ concerning regional autonomy). CSIS working paper 054, June 2000. See Amri, PuspaDelima. (2000). stipulation has prompted a rapid formation of new regions within a short time. Thus, the new law brings tighter requirements for new region formations. ${ }^{23}$ Similarly, Bert Hofman and kai Kaiser concerns with the short period of decentralization process to be implement, where public services and national cohesion would be beneficial of this process. ${ }^{24}$

According to Gabe Ferrasi, more than one year into decentralization, much unclarity remains on what exactly has been decentralized. Law 22 does not define local government functions directly, but only by specifying what the center (Art.7) and the province (Art 9) do. Article 11 specifies local government obligatory functions, but not to a level of operational detail. PP25/2000 is not much help here, as it focuses on the remaining functions of central and regional governments. This

Dampakekonomidanpolitik UU No. 22 dan 25 tahun 1999 tentangotonomidaerah. (The political and economy impacts of Law No. 22 and $25 / 1999$ concerning regional autonomy). CSIS working paper 054, June 2000. Also see Suwondo, Kutut. (2002).

Decentralization in Indonesia.INFID background paper on decentralization.Downloaded from: www.infid.com Quoted in R. E. D. Darmawan, p. 25.

${ }^{23}$ R. E. D. Darmawan, p. 26.

${ }^{24}$ B. Hofman and K. Kaiser, Decentralization, Democratic Transition, and Local Governance in Indonesia, p. 82 in P. Bardhan and D. Mookherjee (edn), Decentralization and Local Governance in Developing Countries: A Comparative Perspective, The MIT Press, Cambridge, London, 2006. 
Beche Bt Mamma | Decentralization in Indonesia:

an Evaluation of the Implementation of Laws 22 and 25 of 1999

legal framework of "general competency" rather than ultra vires definition of function as embedded in Law 5/1974 is unusual for local governments. It is also more radical than the subsidiarity principle-which was apparently the inspiration of the drafting team.9 Subsidiarity as a principle would not call for a limited list of central functions in the law, but for a process by which decentralization or centralization is determined, while specifying the principles that guide the process. ${ }^{25}$ Furthermore, much of the detail on government functions is contained in such ministerial decrees. Moreover, even though regional regulations (PERDAs) are placed below central government legal instruments such as government regulations and Presidential Decrees, arguably organic regional regulations (i.e. based directly on a law that delegates regulatory responsibility to the regions) should take precedent over central regulations and decrees without a

${ }^{25}$ Gabe Ferazzi, (2002): Obligatory Functions and Minimum Standards: A Preliminary Review of the Indonesian approach GTZ SfDM, Report No/2002-2, March. Quoted in B. Hofman and K. Kaiser, The Making of the Big Bang and Its Aftermath: A Political Economy Perspective, Paper presented in the Conference : Can Decentralization Help Rebuild Indonesia?, A Conference Sponsored by the International Study Program, Andrew Young School of Policy Studies, Georgia State University, May 1-3, 2002, p. 2 ,

http://www1.worldbank.org/publicsector/Learning Program/Decentralization/Hofman2.pdf, consulted on 13 November 2014. direct basis in the law. ${ }^{26}$ Worse, some central agencies, notably those for Land management and for Investment Approval have managed to get a Presidential Decree issued which exempts their authorities from decentralization as Law 22/99 calls for. And the adjustment of sectorial laws to align them with regional autonomy, as is called for in Law 22/99 Art. 133. Finally, the revised Art.18 of the constitution now calls for central functions to be regulated by Law, and the question is whether that law is Law 22/99, or whether a separate law is called for to specify these functions. ${ }^{27}$ The bottom line of all this is that the distribution of functions, let alone the expected performance in exercising the functions, is still far from clear. Beyond causing utter confusion in the regions, this

${ }^{26}$ B. Hofman and K. Kaiser, The Making of the Big Bang and Its Aftermath: A Political Economy Perspective, Paper presented in the Conference : Can Decentralization Help Rebuild Indonesia?, A Conference Sponsored by the International Study Program, Andrew Young School of Policy Studies, Georgia State University, May 1-3, 2002, p. 2,

http://www1.worldbank.org/publicsector/Learning Program/Decentralization/Hofman2.pdf, consulted on 13 November 2014.

${ }^{27}$ B. Hofman and K. Kaiser, The Making of the Big Bang and Its Aftermath: A Political Economy Perspective, Paper presented in the Conference : Can Decentralization Help Rebuild Indonesia?, A Conference Sponsored by the International Study Program, Andrew Young School of Policy Studies, Georgia State University, May 1-3, 2002, p. 2,

http://www1.worldbank.org/publicsector/Learning Program/Decentralization/Hofman2.pdf, consulted on 13 November 2014. 
Beche Bt Mamma | Decentralization in Indonesia:

an Evaluation of the Implementation of Laws 22 and 25 of 1999

state of play not only undermines

accountability of the regional government,

but also hampers judgment on the vertical

distribution of fiscal resources. The

confusion has not stopped central

government to embark on an effort to have

the regions "recognize" their functions in a

positive list that is to be cleared by

Presidential. Without deeper

understanding and agreement on the

functions themselves, and the minimum

standards for these functions, recognition

of these functions seems distracting at

best. $^{28}$

\section{The strengths of decentralization}

Despite the several flaws in the implementation, the laws 22 and 25 of 1999 has provided major changes in the decentralization implementation in Indonesia. Firstly, the hierarchical relationship between the province and the districts has been abolished. The kabupaten and kota formly as kotamadya no longer report to the province. They are autonomous regions which have

\footnotetext{
${ }^{28}$ B. Hofman and K. Kaiser, The Making of the Big Bang and Its Aftermath: A Political Economy Perspective, Paper presented in the Conference : Can Decentralization Help Rebuild Indonesia?, A Conference Sponsored by the International Study Program, Andrew Young School of Policy Studies, Georgia State University, May 1-3, 2002, p. 2,

http://www1.worldbank.org/publicsector/Learning Program/Decentralization/Hofman2.pdf, consulted on 13 November 2014.
}

becomethe focus of sub national governance in Indonesia. ${ }^{29}$ They are responsible for a widerange of functions, they can communicate directly with central government, and they are incharge of administering the sub-districts (kecamatan). The second major change is the greatly expanded role of the local elected assemblies, the DPRDs. They now have significant legislative powers; they appoint the heads of regions who are then responsible to the DPRDs; and they are entrusted with the task of 'implementing democracy.' This points to a third change-a greater concern with democratic accountability. ${ }^{30}$ This is indicated in provisions for public disclosure and transparency in government, and in the encouragement of partnership with civil society. Not only is there a concern for more accountability but also for accountability to local citizens rather than to Jakarta.

The fourth major change is the transfer of responsibility for a long list of functions to the kabupaten and kota. These include public works, health, education and culture, agriculture, communication,

\footnotetext{
${ }^{29}$ M. Turner, Implementing Laws 22 and 25: the Challenge of Decentralization in Indonesia, Asian Review of Public Administration, vol. XIII, no. 1, 2001, pp. 72-73.

${ }^{30} \mathrm{M}$. Turner, Implementing Laws 22 and 25: the Challenge of Decentralization in Indonesia, Asian Review of Public Administration, vol. XIII, no. 1, 2001, pp. 72-73.
} 
Beche Bt Mamma | Decentralization in Indonesia:

an Evaluation of the Implementation of Laws 22 and 25 of 1999

industry and trade, capital investment, environment, land, cooperatives and 'manpower' affairs. ${ }^{31}$ This means that the parallel organizations of dinasand kandop will be amalgamated under the control of the autonomous regions while some former provincial functions will also be absorbed by the kabupatenand kota. Related to this is the final change introduced under Law 22-the creation of regional civil services. Large number of former central government employees will be transferred to autonomous regional government control. The kabupaten and kota have been awarded 'the authority to conduct appointment, transfer, dismissal, stipulation of pension, salary, allowance and employee welfare as well as education and training' (Law 22, Article 76). The autonomous regions can structure their organizations according to their own preferences. ${ }^{32}$ The profound changes introduced in Law 22 naturally have strong implications for financial arrangements. These have been addressed in Law 25 of 1999 on the Financial Balance between Central and Regional Government. Two leading transfers from central to sub

\footnotetext{
${ }^{31}$ M. Turner, Implementing Laws 22 and 25: the Challenge of Decentralization in Indonesia, Asian Review of Public Administration, vol. XIII, no. 1, 2001, pp. 72-73.

${ }^{32} \mathrm{M}$. Turner, Implementing Laws 22 and 25: the Challenge of Decentralization in Indonesia, Asian Review of Public Administration, vol. XIII, no. 1, 2001, pp. 72-73.
}

national levels have been abolished: the subsidi daerahOtonomi (SDO) for paying local public servants and routine expenditures and the block Inpresgrants intended to fund development projects. These are replaced by a General Allocation Fund which is to be at least 25 percent of domestic revenue. Ninety percent of this fund goes to kabupaten and kota and ten percent to provinces distributed to individual sub national territories according to a special formula. ${ }^{33}$

The most significant and contentious fiscal change is the introduction of revenue sharing between central and regional governments involving land and building tax, land acquisition, forestry, fisheries, mining, and oil and gas. For example, the central government will take 85 percent of oil revenues after tax while the region from which the oil was extracted will receive the remaining 15 percent. ${ }^{34}$ Other initiatives include a Special Allocation Fund which may be used to finance special initiatives in the regions, and granting regions greater possibilities for securing loans but simultaneously increasing

\footnotetext{
${ }^{33} \mathrm{M}$. Turner, Implementing Laws 22 and 25: the Challenge of Decentralization in Indonesia, Asian Review of Public Administration, vol. XIII, no. 1, 2001, pp. 72-73.

${ }^{34} \mathrm{M}$. Turner, Implementing Laws 22 and 25: the Challenge of Decentralization in Indonesia, Asian Review of Public Administration, vol. XIII, no. 1, 2001, pp. 72-73.
} 
Beche Bt Mamma | Decentralization in Indonesia:

an Evaluation of the Implementation of Laws 22 and 25 of 1999

regional accountability for them. There is in general an increased concern with financial accountability not only upwards to central government but also to the DPRDs which have been awarded the authority to reject the regional head's annual accountability report. ${ }^{35}$

\section{Conclusion}

The implementation of decentralization in Indonesia has brought a fresh air in the government administration system in regards to the transfer power and authority from the central government to the provinces and sub-provinces. Despite it is as a popular policy, the poor implementation of this decentralization, particularly law 22 and 25 of 1999 that has been discussed in this essay, has influenced the performance and output of the policy. Thus, Indonesia government should doaccurate assessment to ensure the implementation of this policy will encourage the public services, the transfer power and the fiscal benefits in Indonesia.

\section{Bibliography}

A. Bayhaqi, Decentralization in Indonesia: the Possible Impact on Education (Schooling) and Human Resource Development for Local Regions, Southeast Asian Studies Programme National University of Singapore, 2004, p. 3. Paper presented at The 2nd International Conference on Indonesia: Decentralization and Structural Reformation, Faculty of Social and Political Sciences, Diponegoro University, Semarang, July 78th,2004.

http://www.rand.org/content/dam/ rand/www/external/labor/FLS/IF LS/papers/2004_bayhaqi.pdf, consulted on 12 November 2014.

Amri, PuspaDelima, Dampakekonomidanpolitik UU No. 22 dan 25 tahun 1999 tentangotonomidaerah. The political and economy impacts of Law No. 22 and $25 / 1999$ concerning regional autonomy. CSIS working paper 054, June 2000 .

B. Hofman and K. Kaiser, The Making of the Big Bang and Its Aftermath: A Political Economy Perspective, Paper presented in the Conference : Can Decentralization Help

\footnotetext{
${ }^{35} \mathrm{M}$. Turner, Implementing Laws 22 and 25: the Challenge of Decentralization in Indonesia, Asian Review of Public Administration, vol. XIII, no. 1, 2001, pp. 72-73.
} 
Beche Bt Mamma | Decentralization in Indonesia:

an Evaluation of the Implementation of Laws 22 and 25 of 1999

Rebuild Indonesia?, A

Conference Sponsored by the

International Study Program,

Andrew Young School of Policy

Studies, Georgia State University,

May 1-3, 2002, p. 2,

http://www1.worldbank.org/publicsector/L

earningProgram/Decentralization/

Hofman2.pdf, consulted on 13

November 2014.

Gabe Ferazzi, (2002): Obligatory

Functions and Minimum

Standards: A Preliminary Review

of the Indonesian approach GTZ

SfDM, Report No/2002-2, March.

Quoted in B. Hofman and K.

Kaiser, The Making of the Big

Bang and Its Aftermath: A

Political Economy Perspective,

Paper presented in the Conference

: Can Decentralization Help

Rebuild Indonesia?, A

Conference Sponsored by the

International Study Program,

Andrew Young School of Policy

Studies, Georgia State University,

May 1-3, 2002, p. 2,

http://www1.worldbank.org/publicsector/L

earningProgram/Decentralization/

Hofman2.pdf, consulted on 13

November 2014.

K. Green, Decentralization and Good
Indonesia, Munich Personal rePEcArchieve, MPRA Paper no. 18097, 26 October 2009, p. 1.

M. Turner, Implementing Laws 22 and 25: the Challenge of Decentralization in Indonesia, Asian Review of Public Administration, vol. XIII, no. 1, 2001, pp. 72-73.

P. Smoke and B. D. Lewis, Fiscal Decentralization in Indonesia: A New Approach to an Old Idea, World Development, vol. 24, no. 8, p. 1282.

R. R. Simatupang, Evaluation of Decentralization Outcomes in Indonesia: Analysis of Health and Education Sectors, A Dissertation Submitted in Partial Fulfillment of the Requirements for the Degree of Doctor of Philosophy in the Andrew Young School of Policy Studies of Georgia State University, 2009, p. 1.

R. E. D. Darmawan, The Practices of Decentralization in Indonesia and Its Implication on Local Competitiveness, Public Administration-Public

Governance Study, School of Management and Government, University of Twente, Enschede, The Netherlands, 2008, p. ii.

Governance: the case of 
Beche Bt Mamma | Decentralization in Indonesia:

an Evaluation of the Implementation of Laws 22 and 25 of 1999

R. R. Simatupang, Evaluation of

Decentralization Outcomes in

Indonesia: Analysis of Health and

Education Sectors, A Dissertation

Submitted in Partial Fulfillment

of the Requirements for the

Degree of Doctor of Philosophy

in the Andrew Young School of

Policy Studies of Georgia State

University, 2009, p. 1.

T. B. Pepinsky and M.M. Wihardja, Decentralization and Economic

Performance in Indonesia, 10

December

2010,http://www.researchgate.net

/publication/228427343_Decentra

lization_and_economic_performa

nce_in_Indonesia/links/00463524

$2 \mathrm{ae} 33 \mathrm{e} 3 \mathrm{ca} 4000000$, consulted on

12 November 2014. 